\title{
Differentiation of Complicity in the Commission of Crimes in the Field of Non-Cash Payments
}

\begin{abstract}
Shahbazov R.F.* Plohih G.I. Tarykin V.K.
The Southwest State University, SWSU, The Southwest State University, SWSU

"Corresponding author. Email: Ramiz1999@yandex.ru

ABSTRACT

This article analyzes the legal regulation of non-cash payments in the Russian Federation in the context of considering the imperfection of legal regulation of the relevant area as a factor that has a negative impact on the criminal situation in the Russian state. Within the framework of this article, the authors concluded that the current Russian legislation does not keep pace with the dynamics with which electronic payments are developing, which, in turn, is evidenced by incomplete legal regulation of various ways in which electronic money is used. Statistical data are provided, from which it follows that after a certain amount of time, the number of payments made with plastic cards, as well as the number of payments made in cash, will remain at the same level. At the same time, unfortunately, we have to state that the growth in the number of payments in non-cash form is accompanied by a concomitant increase in fraud. Attention is focused on the role of differentiation of complicity in countering crime in the field of non-cash payments.
\end{abstract}

Keywords: crime, complicity, differentiation, non-cash payments, criminal situation, payment systems, the

Central Bank of the Russian Federation, electronic money

\section{INTRODUCTION}

There is no doubt that the issue of improving the legal regulation of non-cash payments in the Russian Federation is relevant.

It seems that the main factors influencing the improvement of the regulatory framework for regulating non-cash payments in Russia are the sufficiency and sensitivity of the attention shown by the legislator to regulatory legal acts in the field of Informatics, contracts concluded regarding the exchange of electronic documents, as well as legal liability for such actions as distortion or loss of banking information.

There are various measures, the adoption of which may well lead to a more effective legal regulation of non-cash payments from the point of view of ensuring information security. One of these, in turn, is an administrative measure, the essence of which is to expand the powers of the Central Bank of Russia in the area we are considering. At the same time, it is possible to implement this option by excluding from article 862 of the Russian Civil code regulations that refer to the fact of regulating legal relations related to settlements directly by Federal laws [2].

In the doctrinal literature, when considering and discussing issues concerning the normative legal regulation of relations related to the implementation of non-cash payments, attention is often focused on the belonging of the relevant legal relations to a particular branch of law.

The classic position is based on the point of view that the sphere of non-cash payments should be referred to the subject of financial law, since non-cash payments receive their legal regulation from the body of legislation that has essentially formed the financial and legal acts of the Russian Central Bank.

\section{MATERIAL AND METHODS}

The study was based on the general philosophical dialectical method of scientific knowledge. In addition, private scientific methods were used, namely, systemstructural, formally-logically, statistical and others.

\section{RESULTS}

An important role in countering crime in the field of noncash payments is played by differentiation of complicity in the Commission of a crime.

Differentiation in Russian criminal law has a significant applied significance.

Lack of effective legal regulation of clearing settlements in the Russian Federation has a negative impact on the crime situation in the country.

a mandatory solution requires such a problem as the lack of full regulation of the state of security of the use of payment means such as electronic money. First of all, we are referring to such areas as:

1. withdrawal of funds;

2. confidentiality of personal data provided; 
3. getting compensation for program failures.

Accordingly, it is possible to conclude that it is in these areas that there is a "ground" for the implementation of fraudulent intentions, which, in turn, further determines the need to ensure the security of electronic money systems [5].

A positive attitude is caused by the idea of the need to legislate the criteria for attributing a particular monetary asset to a monetary surrogate.

In accordance with the Federal law «on the Central Bank of the Russian Federation (Bank of Russia)», as well as the Constitution of the Russian Federation, the ruble is the Federal currency of the Russian state, the issue of which is the exclusive competence of the Central Bank of the Russian Federation.

In addition, Russian legislation prohibits the introduction and issuance of monetary surrogates on the territory of Russia.

The European Central Bank has proposed a classification of money surrogates depending on the legal regime:

1. centralized issuance:

- physical form: coupons, coupons, national currency;

- digital form: online coupon, virtual currency;

2. issue carried out in a decentralized manner:

- physical form: commodity money;

- digital form: platforms for currency operations;

- digital form (with cryptographic protection): cryptocurrency.

We can say that in today's conditions, such means of payment as the following do not receive the necessary legal regulation in the Russian state:

- virtual currency;

platform for foreign exchange transactions;

- digital currency.

Based on the above, it becomes obvious that the current Russian legislation does not keep up with the dynamics with which electronic payments are developing, which, in turn, is evidenced by incomplete legal regulation of various ways in which electronic money is used.

\section{DISCUSSIONS}

In the context of this topic, it is impossible not to pay attention to payment systems. In particular, it should be noted that their regulation is carried out by information and legal, as well as financial and legal norms.

Assessing the structure of the components of the non-cash payment system, it is possible to state that its regulation is carried out by mandatory regulatory legal acts of the Central Bank of Russia [4].

It is noteworthy that functions related to the control and regulation of non-cash payments can be performed not only by state bodies [10]. It is allowed to delegate some of these functions to legal entities, as well as individuals who do not have the status of a state body or official.

So, for example, the decision of the constitutional Court of the Russian Federation dated 12.10.1998, № 24-P «On business about check of constitutionality of paragraph 3 of article 11 of the Law of the Russian Federation of
27.12.1991 of the year» about bases of tax system in the Russian Federation», can be stated to designate credit institutions or banks numerous functions of a public law nature [3].

The above is expressed, for example, in the fact that the execution of settlement legal relations is accompanied by the implementation of financial control by credit organizations of the activities of their clients.

Thus, based on the above, it is acceptable to assume that legal relations in the sphere of non-cash payments are regulated to a certain extent, and the legal framework for regulating these legal relations consists mainly of mandatory financial and legal acts of the Central Bank of the Russian Federation.

Analysis of statistical data shows that the trend associated with the transition of Russian citizens to cashless payments is increasing (graph 1).

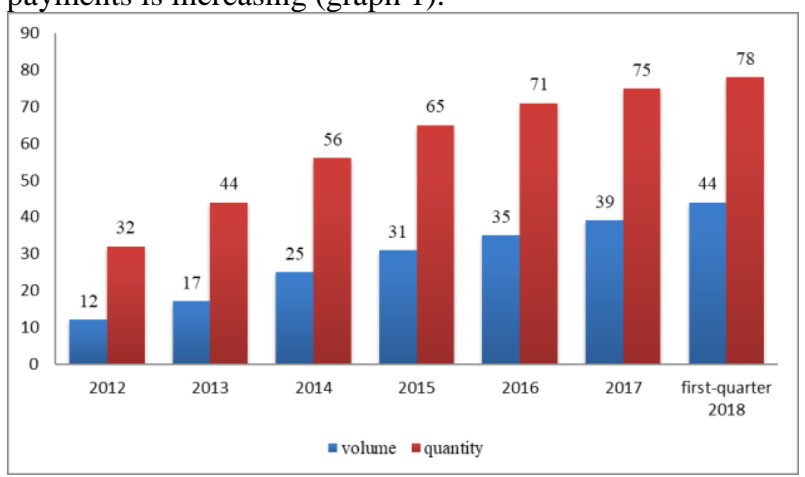

Graph 1 Share of non-cash payments in transactions with payment cards in volume and quantity terms \%

According to the statistical data reviewed, it is possible to conclude that after a certain amount of time, the number of payments made with plastic cards, as well as the number of payments made in cash, will remain at the same level. At the same time, unfortunately, we have to state that the growth in the number of payments in non-cash form is accompanied by a concomitant increase in fraud.

For clarity, we will indicate which methods are most often used by scammers:

1) theft carried out through the use of remote terminals -58 $\%$;

2) theft committed using ATMs-40\%;

3 ) theft carried out through electronic money settlements $2 \%$.

Recently, hackers are using so-called phishing attacks, which, in turn, should mean deception or social development of clients of organizations in order to subsequently steal their identification data, as well as transfer their confidential information for criminal use [9]. Phishing attacks are usually implemented in the following ways:

1. the use of electronic mail and spam;

2. using web content;

3. IRC and IM message transmission;

4. the use of Trojans. 
Bringing to responsibility for the Commission of a criminal act by two or more persons was carried out during the Kievan Rus, which gives complicity in the crime the status of the oldest criminal law institution.

The first legal act that provided for the punishment of crimes committed by several persons, not one, was the Russian truth, according to article 40 of which: "If one sheep, goat or pig is stolen, and one sheep is stolen by 10 (people), then let them put a fine of 60 rubles (each)...» [6]. In turn, during this period of development of the Russian state, the definition of complicity at the legislative level has not yet been developed.

With regard to complicity, it can be noted that the role of the accomplice was given special attention in such a normative legal act as the Code of criminal and correctional punishments of 1845 . Thus, article 15 of the Code on criminal and correctional punishments defined an accomplice by listing the methods of accomplishing the act. A more concise definition of the concept of an accomplice was already given in the Criminal code of 1903.

In the future, with the formation of Soviet Russia, the concept of complicity was characterized by its vague interpretation until 1922, when the criminal code of the RSFSR improved the rules relating to the institution of complicity - the need to determine the degree of participation in sentencing, as well as the degree of danger, both the criminal himself and the criminal act that was committed by him.

Significant changes in the regulation of the institution of complicity in crime occurred with the adoption of the Fundamentals of criminal legislation of the USSR and the Union republics in 1958. In accordance with this normative legal act, it was stated that "an Accomplice is a person who assisted in the Commission of a crime with advice, instructions, as well as a person who promised in advance to hide the criminal by criminal means" [8].

The criminal code of the RSFSR of 1960 completely duplicated the concept of aiding and abetting from the Foundations of the criminal legislation of the USSR and the Union republics of 1958

Analysis of the current Criminal code of the Russian Federation (hereinafter - the criminal code of the Russian Federation) allows us to state that the Russian legislator ambiguously refers to complicity. For example, criminal liability is established for complicity in the Commission of crimes under article 205 (Terrorist act), part 3 of article 206 (taking a hostage), part 1 of article 208 (Organization of an illegal armed group or participation in it) Criminal code of the Russian Federation.

Complicity in the commission of these crimes was criminalized and marked by a separate norm of the special part of the criminal code of the Russian Federation due to the high degree of public danger of the corresponding acts. Thus, an example of already implemented differentiation of complicity was given above, but only in specific cases. However, it seems appropriate to differentiate complicity in the general part of the criminal code of the Russian Federation, based also on such criteria as the degree of public danger presented.
Russian criminal law provides for the contents, aided in part 5 of article 33 of the criminal code, under which an accomplice is «a person involved in the Commission of crime by councils, instructions, granting of information, means or tools of commission of crime or removal of obstacles, as well as person who previously promised to conceal the offender, means or tools of Commission of crime, traces of crime or items obtained by criminal means, as well as the person who previously promised to acquire or sell such subjects».

Of course, the question may arise about whether or not to distinguish among different types of complicity in the criminal law and is more appropriate to leave in the general part of the criminal code provision for complicity as it is today, after the allocation of complicity, as such, was sufficient, as the Russian legislator considered the role of accomplice, has different legal consequences for the implementation of this role.

Answering this question, in the context of the above position, we can also say that the categorization of criminal acts, as well as the differentiation of crimes carried out in the Special part of the criminal code, depending on the nature and degree of their social danger, were also not necessary, since it was quite possible to limit the definition of «crime» and at the legislative level to establish one criminal penalty for committing an act that falls under the definition of a crime.

Thus, it is obvious that the Criminal code of the Russian Federation is a clear example of the feasibility and necessity of differentiation. Aiding and abetting should certainly be subjected to the same procedure. To justify this proposal, we should first consider the essence of differentiation in criminal law.

The doctrine of criminal law traces a considerable number of scientific works devoted to the differentiation of criminal responsibility. At the same time, differentiation is often considered, along with individualization, with emphasis on the fact that these are two different types of activity. Moreover, some scientists even suggest that differentiation should be recognized as one of the principles of Russian criminal law at the legislative level [7].

The essence of differentiation is that the legislator sets different legal consequences depending on such criteria as the nature and degree of public danger of the act. In addition, differentiation of criminal responsibility contributes to the realization of such a goal of criminal punishment as correction of the convicted person, as well as prevention of the commission of new (new) crimes.

So, if you imagine that for the commission of a different nature and degree of public danger of criminal acts, like murder and slander, sanctions of the appropriate articles of the Special part of the criminal code envisages similar measures of criminal responsibility, then come to a conclusion about the occurrence of this for society and the state solely on negative consequences will be easy, because the effectiveness of the preventive impact of the Russian criminal law will be reduced.

Differentiation reflects a versatile approach of the legislator to the manifestation of different dangerous 
behavior. It is possible that after a person has committed a criminal act classified as moderate, in the future, even after he has incurred criminal responsibility, he does not have a motive to commit a more serious crime. In this case, a person who has already served a sentence for committing a medium-gravity crime may stop before committing, for example, a serious crime because of the understanding of the possible execution or serving of a more severe criminal sentence. On the other hand, the understanding of a person who has committed a crime, for example, of medium gravity, that when they commit a crime of a more serious category will not entail a more severe criminal punishment may serve as a kind of incentive to commit new crimes.

Let's imagine a situation in which a person decided to commit theft, for example, due to difficult life circumstances, for example, due to a poor financial situation. The most dangerous form of theft for human health and life is robbery, since it implies the use of violence that is dangerous to life or health, or the threat of such violence, which is not implied by such forms of theft as theft and robbery.

Of course, the ideal development of events would not be the Commission of any crime by this person at all. However, if they are still motivated to improve their financial situation by criminal means, then it is better to choose the lesser of all the «evils», i.e. it is preferable that they commit theft or, in extreme cases, robbery instead of committing a crime under article 162 of the criminal code of the Russian Federation. With identical criminal liability for theft, robbery and robbery, the attacker will not think about the possible legal consequences, because in any case, they will be the same. Accordingly, the probability of choosing robbery as a method of enrichment increases.

The evidence that the russian legislator adheres to this approach is the presence of administrative pre-emptions in the russian criminal legislation. Administrative prejudice acts as a tool for influencing a person who displays deviant behavior. Administrative prejudice allows you to counteract progressive illegal behavior, preventing its transformation from an administratively punishable to a criminal offense. This is the purpose of administrative pretrial procedures in criminal law.

\section{CONCLUSION}

In conclusion, it is possible to concluded about the negative impact of insufficient legal regulation of non-cash payments in the Russian Federation on the criminal situation in the country.

Legal relations in the sphere of non-cash payments are regulated to a certain extent, and the main legal framework for regulating these legal relations consists of mandatory financial and legal acts of the Central Bank of the Russian Federation.

Differentiation of criminal responsibility is an effective tool of the Russian legislator aimed at countering the growth of crime.

It is necessary to adhere to the point of view that differentiation of criminal responsibility contributes to the criminal law counteraction of recidivism. For example, when a person commits a crime for the first time, it is necessary from the point of view of protecting public relations to make it clear to the convicted person that the repetition of criminal activity will entail more severe legal consequences for him than those to which he was subjected earlier. This will serve as a psychological barrier for the person to commit a new crime or crimes.

In addition, differentiation of criminal responsibility contributes to the implementation of the principle of saving criminal law repression. In other words, using the volume of measures of criminal legal influence that is available, applying immediately to the person who committed a crime for the first time, the most severe measure, when the relevant person commits a new crime or crimes, less strict measures of criminal legal influence may not be as effective.

It is obvious that the current Russian legislation does not keep up with the dynamics with which electronic payments are developing, which is evidenced, in turn, by the incomplete legal regulation of various ways in which electronic money is used.

The criteria established by Russian legislation for classifying a particular monetary asset as a monetary surrogate helps to curb the criminogenic impact of insufficiently effective legal regulation of non-cash payments in Russia.

\section{REFERENCES}

Expand the powers of the Central Bank of Russia in the area we are considering. To do this, in turn, by excluding from article 862 of the Russian Civil code regulations that refer to the fact of regulating legal relations related to settlements directly by Federal laws.

[1] the Constitution of the Russian Federation the Constitution of the Russian Federation (adopted by popular vote 12.12.1993)// ATP «Consultant»

[2] the Civil code of the Russian Federation (part two) of 26.01.1996 No. 14-FZ (ed. from 18.03.2019, with amendments. from 03.07.2019) // ATP «Consultant»

[3] Decision of the constitutional Court of the Russian Federation dated 12.10.1998 No. 24-P "On business about check of constitutionality of paragraph 3 of article 11 of the Law of the Russian Federation of 27 December 1991 «On established tax system in the Russian Federation»// ATP «Consultant»

[4] A.V. Agranovsky Legal regulation of cashless payments in business activities on the territory of the Russian Federation. Moscow: Lomonosov Moscow state University (MSU), 2016. 397 p. 
[5] A. Gutorova, M. Urda, S. Sheveleva To the question about the essence of scientific fraud // SGEM International Multidisciplinary Scientific Conference on Social sciences and Arts. 2017. no. 1-2. Pp. 813-818.

[6] Monuments of Russian law. M. 1952. Issue 1: Monuments of law of the Kiev state: $\mathrm{x}$-third century. in order. S. V. Yushkova. 287 PP.

[7] Yu. I. Lyapunov Principles of criminal law // Socialist legality. 1989. no. 2. Pp. 32-34.

[8]

URL:http://pravolevonevsry.org/baza/soviet/sssr6067.ht m.

[9] A. A. Luneva Fraud in the sphere of cashless settlement / / Alley of Sciences. 2018. 10 (26). Pp. 174178.

[10] M. V. Vronskaya Calculations on checks / / YuristPravoved. 2017. no. 3. Pp. 67-72 